\title{
A Delphi Study On Online Qur'ānic Themes
}

\author{
Ashraf Ali Salahuddin, Roslina Othman \\ Dept of Library and Information Science, International Islamic University Malaysia, Kuala Lumpur, Malaysia \\ ashraf.ali@live.iium.edu.my \\ Dept of Library and Information Science, International Islamic University Malaysia, Kuala Lumpur, Malaysia \\ roslina@iium.edu.my
}

\begin{abstract}
Thematic interpretations of al-Qur'ān ( $\mathrm{TlaQ}$ ) has a sensitivity due to the interrelation of Qur'ānic verses/ verse with each other. The purpose of this research was to extract the online Qur'anic search engines (OQSE) and investigate the existing thematic interpretations of al-Qur'an (TlaQ) based on the alignment with their relevant verses. The OQSEs provide the list of themes and the aligned verses theme and the aligned rhyme in their websites. The ambiguous thematic search engines have the possibility to mislead the user by retrieving nonaligned verses against a certain subject/theme (query) or the user may not fully understand the interpretations due to the incomplete results. The extracting of themes/topic and the aligned verses have been conducted using Cranfield's Index Device method. Then a two-round Delphi method has been applied to justify the existing themes and the aligned verses by 20 experts of Qur'anic discipline. There are $\mathbf{2 4 0}$ themes and $\mathbf{4 0 0}$ verses have been extracted and categorized into 40 thematic groups (TG). The experts' justification through Delphi method has revealed that the accuracy of ordinated thematic groups in OQSE is 40\% (16/40) only and the accuracy of the ordination of the themes and the verses achieved $35.41 \%$ (85/240). Despite the significant outcome of this research, the limitation recommends that further research should be conducted extracting more themes and aligned verses from OQSEs. Instead of 20 experts in Delphi, future research can concentrate on a big number of experts to investigate all the thematic verses of entire Qur'ān.
\end{abstract}

Keywords—Delphi; Thematic interpretation; Tafseer; Qur'ānic search, Qur’anic theme.

\section{INTRODUCTION}

The relevant results are the most important outcome of any search engine. Every Information Retrieval (IR) system's target is to retrieve the results first and then gives relevance feedback of the retrieved items to its users. Ultimately, the relevant results are the main goal of an IR. It is assumed that the retrieval performance of a search engine is an endless study process. Many types of research and experiments are being done to make the search engine platform to be a better information retrieval (IR) platform. Although the process is ongoing [1] [2], [3] thought that there was no suggested confirmation that the retrieval ranking had been improved in the last 20 years. Meaning that, in the past few years, although there were many experiments and researches have been undertaken but the result to make the retrieval performance could not gain the level of satisfaction.

Accordingly, to find out the most relevant and precise result, or to check out how much precise the result the system has retrieved (Recall) and put in order according to the most relevant to the least (Precision), many ranking functions and relevance judgment models have been brought together by several researchers. The relevance of the documents to a user's query usually is the subjective justification. What is relevant to user $X$ may not be relevant to user $Y$ [4]. Therefore, the idea of ranking eases this kind of users by letting them look through the results according to the probability of relevance. In [5] view, "ranking gives the user control over how much material they have to look at" (2000:784). Meaning that ranking helps users to save time and leaves the justification of relevancy or not relevancy up to them. Because relevancy of a retrieval item to the user's query is very much unpredictable and uncertain. It cannot satisfy everyone but it can let everyone judge his or her own relevancy looking through the retrieval ranking list. Only the point is, how far a user has to look through the list for the relevant items. In this case, the shorter the list is better because if the ranking list for relevancy are too long, it would bore the user, and there is no use of ranking if the user gets bored to check his/her items. In fact, a relevance judgment into the need not to the query [5].

In other words, it is said that the relevance judgment should be justified according to the needs of the user. When a user uses any query, it is the expression of the user or it is considered a question formulated by the user. Hence, the 
answer or the relevance feedback should be according to the question of the user which is the query or what is a user looking for and that is the needs of the user. Despite using the query, it is not always based on the query that a user looks for his/her desired items because the query is the expression and expression sometimes could be wrongly delivered. Therefore, if it is said 'user's needs', it is more suitable than saying 'user's query'. On top of that, since it is the subjective justification, it does not matter what is the query. The matter is what the user needs or wants ultimately after looking into the retrieved results. As a result, the theory derived that the relevance justification is according to users' needs [6]-[8].

\section{STATEMENT OF PROBLEM}

There are many ways previous studies have influenced this research to conduct this research. Such as the creation of hierarchal vocabulary of Qur'ānic concept by applying the term-head principle to identify the important concept of alBaqarah and justified the term by experts of the domain [9]. On this account, the main concept of this research is to identify the sources of Qur'ānic themes and investigate their ordination with their relevant verses.

Accordingly, the collection of index topics from online have been identified without authors as [10] said, "This test collection is based on the collection of manually indexed topics of the al-Qur'ān that is freely distributed on the internet. The author for this collection is unavailable" (p. 157) and the literature introduced merely two online Qur'anic search engines (OQSE) in some research such as islamicity.com and submission.org [11], [12].

However, to investigate, the collection of all the OQSEs with their distributed index topics is necessary and a comparative study with experts' justification is important. To come up with a compilation of themes and verses for thematic interpretations of al-Qur'an (TlaQ), two OQSEs is not sufficient. Thus, the research of [13] has found that the combination of the thesaurus and stemming may have increased the recall of relevant verses of al-Qur'ān but lack of updating the Qur'ānic thesaurus the precision is low. Therefore, it has proven that adding and removing themes of al-Qur'ān can improve the retrieval results. In other words, updating means the existing thematic interpretations of alQur'ān should be revised. Which is why this research has aimed to extract the sources of Qur'anic search and compile the themes with relevant verses. As the authors of those topics are not available and ambiguousness is there, the compilation has been justified by experts using the Delphi method.

However, the main purpose of this research is to extract the sources of online Qur'anic themes and justify through experts' clarification. The objective has focused on two stages. Stage one extracts the sources of online themes with their aligned verses and stage two investigates the relevance feedback of those aligned verses provided in OQSEs by two round Delphi study.

\section{PREVIOUS WORK}

\section{A. Thematic Interpretations of Al-Qur'ān (TlaQ)}

Thematic Interpretations of Al-Qur'ān is constructed based on the main theme or subject of a verse or verses of alQur'ān. A theme merges same meaning or orders (حكم) under one umbrella no matter which Sūrah (سورة) or chapter (حز) the verse belongs to. According to Muslim scholars, which was asserted by [14] that the thematic interpretations refer to, "the gathering of the verses scattered throughout the chapters (سورة) of the al-Qur'ān that deals with a specific subject whether explicitly or implicitly, with a view to interpreting them according to the objectives (مقاصد) of the al-Qur'ān" (2005:2).

\section{B. Existing Methods of Qur'ānic Search Evaluation}

A good deal of research papers found on Qur'ānic text retrieval system in previous research. The purposes of most of these researches are about testing the retrieval performance of Qur'ānic text. The retrieval performance of multi-script Qur'ānic text has been investigated in Indri by [15]. The queries were derived from a set of frequently asked questions (FAQ) posed to experts. They applied the relevance judgement and measured Recall, Precision and Overlap, the test has confirmed that Indri is capable of retrieving multi-script Qur'ānic text.

[12] had an experiment on the representative of index terms in Qur'ānic texts. They believed that concept hierarchy for a specific domain like al-Qur'ān is useful for better retrieval, document classification as well as document browsing. Due to the effectiveness of this task, the hierarchy should be precisely according to the domain and the size should be appropriate. They applied the term reduction approach to control the size of concept hierarchy vocabulary. Transition point (TP) method has been found more effective than other methods like entropy method (EM) and hybrid of EM with VSM method. Measuring index terms checking by VSM-TP (is an effective approach) to redundant the unnecessary terms.

According to [11] and [16], the hypothesis introduced by Salton in their research is the highest frequency is the best and the medium frequency is the expected calibrated one to get as much recall as possible. Which means, medium frequency usually has the tendency to have more semantic in the content. To emphasise on this point, it is clear that recall is important in Qur'ānic text retrieval because relevant verses 
of al-Qur'ān should be retrieved without leaving behind any related verse unretrieved. Nevertheless, when recalling verses of a related theme is important, it is as important either to make the result precise or to focus on the precision level of retrieved verses.

However, in thematic interpretations of Qur'ānic search, highest recall is not enough to satisfy users due to the relational verses of al-Qur'ān based on subjects/themes. Only keywords matching cannot draw a line of good retrieving in this sense of search. It has to be accurate based on the subjects/themes aligning with all the relevant verses.

Accordingly, [10] also has done an evaluation of Qur'ānic text retrieval based on manual indexed topics. In their study, index collections were derived from the Internet, which are freely distributed, and they considered those as the queries for evaluation. Instead of using Indri, they used Terrier and justified the results by consulting experts as well. In the same manner, [9] researched on concept pulling justification from al-Qur'ān using Termine. They used eight English translated al-Qur'ān and the data has been used from Sūrah al-Baqarah only.

On the other hand, the early studies showed how the resources on Qur'annic search retrieval need to be collected. The process shows the category of data and the hierarchical process of collection. The first phase started with the type of data that need to be identified and collected. The second phase does the identification of resources' sources. In the third phase, they introduced how to identify the key metadata before going to extract data from the resources in phase four. However, phases five, six and seven are the process of validating the data by proper personnel and generating total statistics of the entire data.

Likewise, [17] has introduced a four-phase methodology for extracting context from Tafseer al-Qur'ān. Phase one of this research started with manually collecting the text from Tafseer and proceeding for analysis by experts or authors of the perspective Tafseer book. This phase has included chapters, categories, topics, themes, meanings, thesaurus, thoughts, or the combination of this category. The second phase, they have suggested to build up the corpus with digital content for the collection. Phase three implements the validation process for the digital contents including proofreading and verifying the authenticity of the content in the database. This process is done by experts as well. Finally, phase four is meant for distributing the digital content for various purposes to various sources such as for digital application on Qur'ānic search or offline index book of the alQur'ān or Context based al-Qur'ān in many formatsonline/offline etc. Based on the literature, the existing framework for Qur'ānic text retrieval can be conceptualized. This conceptualization is shown in Figure 1.

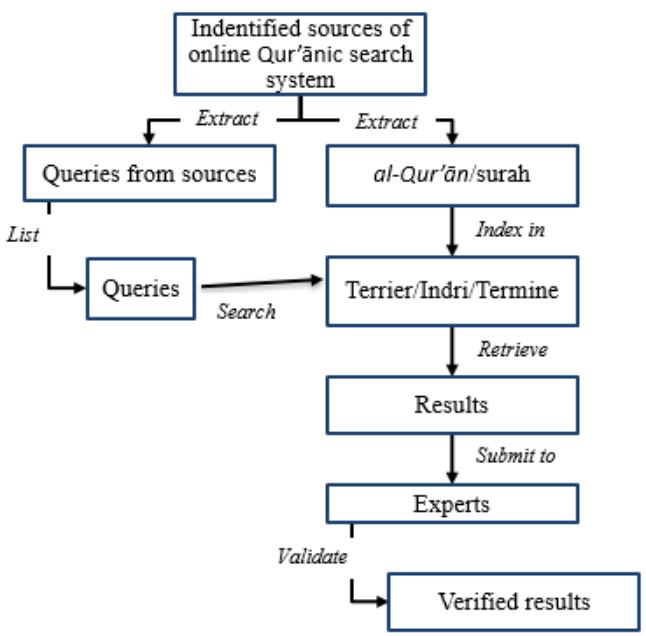

Figure 1. Conceptual Framework for Existing Qur'ānic Search Retrieval System. Source: [10], [11]

Most studies in retrieval frequency of Qur'ānic search started from the extraction of sources e.g. manual collection of books, Tafseer etc. and building up the corpus. This research has conceptualized the overall research works of previous studies in given Figure 1. The process started from identification of sources or resources of Qur'ānic materials such as books, online sources or soft copies. The second process extracts the queries or formulates queries from the identified sources. The next process starts indexing the resources into the system to build up corpus and to justify the retrieval results. The three tools identified by this research have been widely used such as Terrier, Indri and Termine. Accordingly, the formulated queries were extracted from the sources and used to search in the system. The retrieval methods were used the language model such as tf-idf, kl-divergence, BM25 etc.

\section{Delphi Study}

Delphi methods' main purpose is to get the consensus of experts in a certain field through face to face discussion or questionnaire distribution. The method urges the researcher to get into several meetings or discussions with the experts until the consensus reaches the objective of the research. Traditionally it starts with face to face discussion in an openended questionnaire, and then from the second round it goes with the rating and statistical manner. However, many studies have used the range of 2 rounds to three rounds. Even a single meeting has also taken as Delphi and the varieties of sample size seen from 4 (experts) to 171 (experts). Table I shows the varieties of Delphi in other research. 
TABLE I DELPHI METHOD DIVERSITY

\begin{tabular}{|c|c|c|c|}
\hline Literatures & Delphi Focus & Rounds & $\begin{array}{l}\text { Sample } \\
\text { Size }\end{array}$ \\
\hline $\begin{array}{ll}\text { Hartman } & \& \\
\text { Baldwin (1995) } & \end{array}$ & $\begin{array}{ll}\text { Validate } & \text { research } \\
\text { outcomes } & \end{array}$ & 1 & 62 \\
\hline $\begin{array}{l}\text { Rowe \& Wright } \\
\text { (1996) }\end{array}$ & $\begin{array}{l}\text { Forecasting (of } 15 \\
\text { political and economic } \\
\text { events for } 2 \text { weeks into } \\
\text { future) }\end{array}$ & 2 & 5 \\
\hline $\begin{array}{l}\text { Czinkota \& } \\
\text { Ronkainen (1997) }\end{array}$ & $\begin{array}{l}\text { Impact analysis of } \\
\text { changes to the } \\
\text { International business } \\
\text { environment }\end{array}$ & 3 & 34 \\
\hline Kuo \& Yu (1999) & $\begin{array}{l}\text { Identify national park } \\
\text { selection criteria }\end{array}$ & 1 & 28 \\
\hline $\begin{array}{l}\text { Nambisan et } \\
\text { al.(1999) }\end{array}$ & $\begin{array}{l}\text { Develop a taxonomy of } \\
\text { organizational } \\
\text { mechanisms }\end{array}$ & 3 & 6 \\
\hline $\begin{array}{l}\text { Lam, Petri, \& Smith } \\
\text { (2000) }\end{array}$ & $\begin{array}{lr}\text { Develop rules for a } \\
\text { ceramic } \\
\text { process }\end{array}$ & 3 & 3 \\
\hline $\begin{array}{l}\text { Roberson, Collins, } \\
\text { \& Oreg (2005) }\end{array}$ & $\begin{array}{l}\text { Examine and explain } \\
\text { how recruitment } \\
\text { message specificity } \\
\text { influences job seeker } \\
\text { attraction } \\
\text { organizations }\end{array}$ & 2 & 171 \\
\hline Scott (2000) & $\begin{array}{l}\text { Rank technology } \\
\text { management issues in } \\
\text { new product } \\
\text { development projects }\end{array}$ & 3 & 20 \\
\hline $\begin{array}{l}\text { Wynekoop \& Walz } \\
\text { (2000) }\end{array}$ & $\begin{array}{l}\text { Rank the most } \\
\text { important } \\
\text { characteristics of high } \\
\text { performing } \\
\text { personnel. }\end{array}$ & 3 & 9 \\
\hline $\begin{array}{l}\text { R. Schmidt, } \\
\text { Lyytinen, Keil, \& } \\
\text { Cule (2001) }\end{array}$ & $\begin{array}{l}\text { Identify and rank } \\
\text { software development } \\
\text { project risks: an } \\
\text { international } \\
\text { comparative study. }\end{array}$ & 3 & $13-21$ \\
\hline $\begin{array}{l}\text { Keil, Tiwana, \& } \\
\text { Bush (2002) }\end{array}$ & $\begin{array}{lr}\text { Rank } & \text { software } \\
\text { development } & \text { project } \\
\text { risks. } & \\
\end{array}$ & 3 & 15 \\
\hline $\begin{array}{l}\text { Brungs \& Jamieson } \\
(2005)\end{array}$ & $\begin{array}{l}\text { Identify and rank } \\
\text { computer forensics } \\
\text { legal issues. }\end{array}$ & 3 & 11 \\
\hline
\end{tabular}

However, according to the research works using Delphi methods, it is recommended that suitable technique for Delphi methods is to get it modified according to research questions and circumstances of one's research [18], [20].

This research has utilized a modified Delphi strategy to fulfil the second stage of research design to justify and validate the thematic groups and their assigned verses. Many studies have used Delphi studies and the range of Delphi possibilities are seen with so many varieties. From one round studies to three round studies, from 4 sample sizes of experts to 171 experts are used in Delphi study. Therefore, it is said that suitable of Delphi is to get it modified according to research questions and circumstances [18], [20].

[21] Expressed that the Delphi procedure is a technique for acquiring an educated agreement in a few subjects. One of the points of this examination is to distinguish the components in a positive or negative perspective among the disseminated subjects of al-Qur'än all through the web. This Delphi strategy has been ended up being an extremely helpful and handy technique for data gathering. As [22] said that the use of the Delphi method would produce a bigger number of remarkable thoughts, assessments, qualities or judgments than what could be accomplished in gathering dialogue. Since one of the goals of this method is to research the specialists' sentiment that contributes toward the foundation or avocation of Qur'annic subjects or themes, it is trusted that this technique would have the capacity to evoke the specialists' supposition on the basic components of TlaQ.

Besides, with Delphi, the specialists are not overwhelmed or invaded by predominant manner. They are along these lines with more prone to reply in an open, legitimate and target way. In this research, a portion of survey research addresses that survey questions that formed are qualitative and the reactions are in this manner in light of the individual's suppositions and qualities. Delphi is demonstrated as reasonable and suitable for the social affair of this sort of information.

In addition, since the vast majority of the specialists selected in this review are the centre staff of Qur'annic field and also holding a ground position in the associations/organizations, it is essential to cooperate with them in a non-meddlesome manner, without taking up of their time excessively. They react to the poll whenever the timing is ideal, dissimilar to meetings which must be directed amid working hours. The procedure of the Delphi technique included a couple of rounds. Subsequently, it enabled specialists to have more opportunity to consider their thoughts thoroughly before keeping in touch with them. Thus, it prompted a better nature of the reaction.

As articulated by [23] this method is additionally appropriate when gathering data from respondents who have broadly contrasting perspectives that give off an impression of being beyond reconciliation. It permits crossexamination of people from generally scatter topographical areas. In this examination, since the areas of the specialists 
were scattered all through Malaysia, it was more prudent to lead the Delphi strategy as opposed to a meeting, centre gathering or gathering meeting. Delphi additionally guaranteed that the specialists could express their assessment and thought with no obstruction from a companion or the higher expert. The obscurity of the approach empowered the specialists to express their supposition openly, without trading off institutional loyalties or companion amass weight. However, the technique used in this research is the modified Delphi method.

\section{METHODOLOGY}

The research has carried out a quantitative method with comparative research on Qur'ānic text retrieval system. The preliminary data has been collected through comparative research and state-of-the-art has been used for reviewing the existing methods of Qur'ānic text retrieval system. The preliminary data consisted of online Qur'ānic search engines (OQSE) and the thematic interpretations of al-Qur'ān (TlaQ). It has undertaken a Delphi method to justify the collected themes and assigned verses from OQSE through experts' consensus in two rounds of study. The domain used for this research is the thematic interpretations of al-Qur'ān (TlaQ).

The entire research has been divided into two stages:

1. Stage 1: Preliminary data collection (Extraction of OQSE for TIaQ).

2. Stage 2: Validate and justify preliminary data through a modified Delphi method.

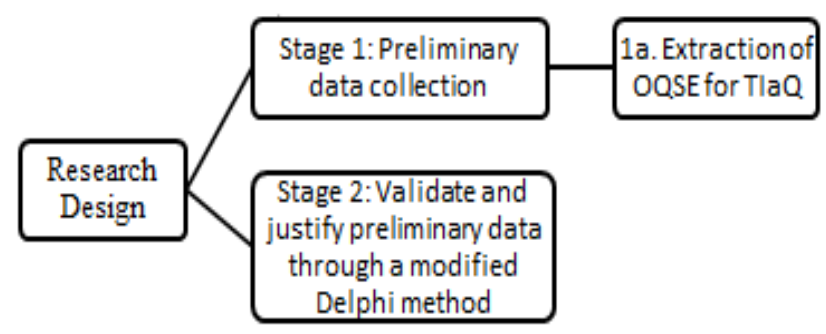

Fig. 2 Research Design

Accordingly, stage 2 has described the justifications of complied themes and verses collected from OQSEs. This stage explains the process of experts' justification in details. Two rounds of Delphi study have been applied to justify the relevance feedback of OQSE's themes and the assigned verses. However, the results identified two sets of themes. Set A, where the experts' responses are positive and Set B, the experts responses are found negative.

\section{A. Preliminary Data Collection}

During comparative research, the online Qur'ānic search engine (OQSE) has been retrieved through Google search engines. In this retrieval, there are 27 OQSEs are found following Cleverdon's Index Device. One research question has been broken into three categories such as important concept, Single words and Main theme (keywords). Thus, the search process has been conducted on Google and found the results on OQSE.

These 27 OQSE have been underlined in three criteria before taking into consideration for next steps such as sources which are retrieved in Google first page, sources which provide the list of index topics and sources which are searchable. According to this criterion, 8 out of 27 OQSEs have been identified which are:

Table II LIST OF OQSE FOR COMPARATIVE RESEARCH

\begin{tabular}{|c|c|c|c|}
\hline $\begin{array}{l}\mathrm{N} \\
\text { o. }\end{array}$ & OQSE links & Description & $\begin{array}{c}\text { Index } \\
\text { Topics } \\
\text { Available }\end{array}$ \\
\hline 1 & $\begin{array}{l}\text { http://www.noble } \\
\text { Qur'an.com/transl } \\
\text { ation/ }\end{array}$ & $\begin{array}{l}\text { Searchable in English but } \\
\text { results do not show } \\
\text { Arabic text of al-Qur'ān. } \\
\text { It shares the same index } \\
\text { as Islamicity }\end{array}$ & Yes \\
\hline 2 & $\begin{array}{l}\text { www.Qur'anindex. } \\
\text { info }\end{array}$ & Searchable in English & Yes \\
\hline 3 & $\begin{array}{l}\text { www.islamicity.co } \\
\text { m/Qur'anSearch }\end{array}$ & $\begin{array}{l}\text { Searchable in English } \\
\text { and Arabic }\end{array}$ & Yes \\
\hline 4 & $\begin{array}{l}\text { www.Qur'ansearc } \\
\underline{\text { h.com }}\end{array}$ & $\begin{array}{l}\text { Searchable with Boolean } \\
\text { and other features but } \\
\text { Arabic text is not } \\
\text { provided in search } \\
\text { results }\end{array}$ & Yes \\
\hline 5 & $\begin{array}{l}\text { www.submission. } \\
\text { org/Qur'an/WinQT } \\
\underline{\text { 2.html }}\end{array}$ & $\begin{array}{l}\text { Search Farsi, Indonesian, } \\
\text { and Swedish } \\
\text { translations. Few } \\
\text { attributes were } \\
\text { mentioned }\end{array}$ & Yes \\
\hline 6 & $\begin{array}{l}\text { http://www.masjid } \\
\text { tucson.org/Qur'an/ } \\
\text { index/qindex_abc. } \\
\underline{\text { html }}\end{array}$ & $\begin{array}{l}\text { Similar to islamicity.org } \\
\text { and run by Submitters }\end{array}$ & Yes \\
\hline 7 & $\begin{array}{l}\text { http://www.musli } \\
\text { m.org/islam/q- } \\
\text { index.htm }\end{array}$ & $\begin{array}{l}\text { Not searchable but } \\
\text { index terms provided }\end{array}$ & Yes \\
\hline 8 & $\begin{array}{l}\text { http://www.citizen } \\
\text { warrior.com/2010/ } \\
\text { og/index-for- } \\
\text { Qur'an.html }\end{array}$ & $\begin{array}{l}\text { Blog of a certain ethnic } \\
\text { group. Provides index } \\
\text { topics but not full al- } \\
\text { Qur'ān. }\end{array}$ & Yes \\
\hline
\end{tabular}

Note: Accessed and collected, May 2016

However, the compilation of all themes and assigned verses along with the verses of Surrah al-Yãseen has been normalized accordingly such as putting all the related themes 
and assigned verses under each respective verse. Example in Figure 3 and 4 below:

Figure 3 and 4 shows the compilation of all themes and assigned verses from the eight OQSEs in line with the verses of chapter 36. Figure 3 shows the normalization process of all those themes and assigned verses together separately under each verse of chapter 36 .

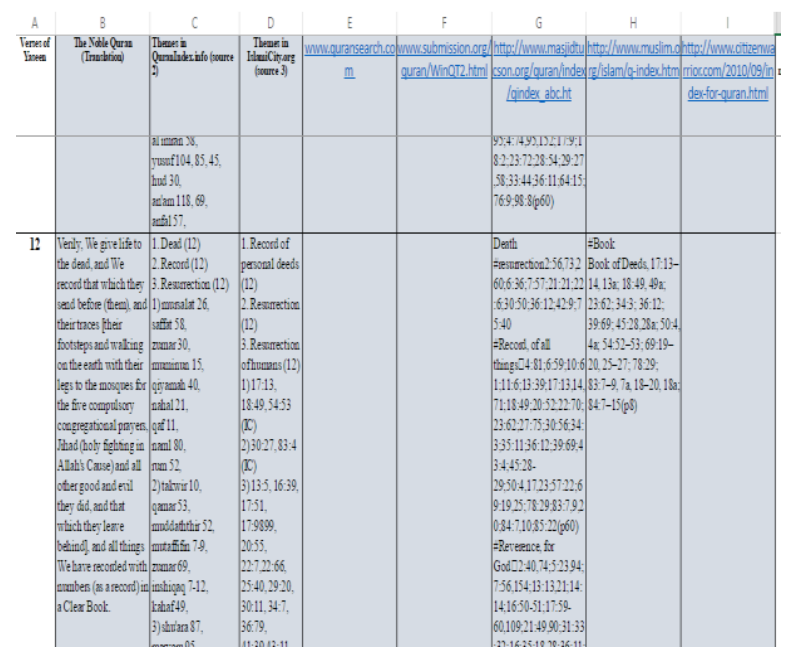

Fig 3 Process of Grouping the Themes and Verses under Each Verse of Chapter 36

\begin{tabular}{|c|c|c|c|}
\hline Yaseenverse & Themes & Relted verses with the themes found in other surah & Source No. \\
\hline \multirow[t]{10}{*}{$36: 12$} & dead & mursalat 26, seffat 58, zumar 30, muminun 15, quyamanh 40, nahi: & 2 \\
\hline & record & 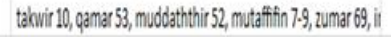 & 2 \\
\hline & resurrection & shu'bra 87, maryam 95, mu'minun 16, tha 1010,102,55, 100, rum & 2,3 \\
\hline & record of personal deeds: & s $17: 13,1849,5,453$ & 3 \\
\hline & resurretion of humans & $13: 5,16: 39,1755,17798999,20555,227,72: 266,25: 40,28: 20,30: 11, ?$ & 3 \\
\hline & death & 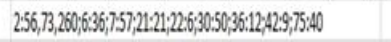 & \\
\hline & record of all things & 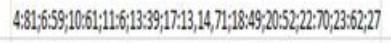 & 6 \\
\hline & reverence & 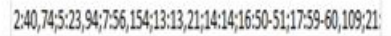 & 6 \\
\hline & book & 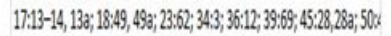 & 7 \\
\hline & book of deeds & 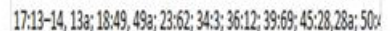 & \\
\hline
\end{tabular}

Fig. 4 Grouping of Themes and Related Verses under Each Verse of Chapter 36

B. Naming the Group Based on the Verses of Chapter 36

After the compilation of themes and assigned verses in line with 83 verses of chapter 36 , each verse of chapter 36 has been named as Thematic Group (TG). Which means, previously extracted themes and assigned verses were compiled under 36:12 (Figure 4), now it is compiled as "Thematic group 12" (Figure 5).

\begin{tabular}{|c|c|c|}
\hline Yaseenverse & Themes & Related verses with the themes found in other surah \\
\hline \multirow{10}{*}{$\begin{array}{l}\text { Thematic } \\
\text { Group }\end{array}$} & dead & mursalat 26, saffit 58 , zumar 30 , muminun 15 , qiyamah 40, nahe \\
\hline & record & takwir 10 , gamar 53 , muddaththir 52 , mutaffifin 7.9 , zumar 69 , in \\
\hline & resurrection & shu'ara 87 , manam 95 , mu'minun 16 , taha $101,102,55,100$, rum \\
\hline & record of personal deeds & s $17: 13,18: 49,54: 53$ \\
\hline & resurrection of humans & $13: 5,16: 39,17: 51,17: 9899,20: 55,22: 7,22: 66,25: 40,29: 20,30: 11, ?$ \\
\hline & death & 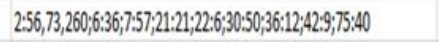 \\
\hline & record of all things & 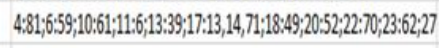 \\
\hline & reverence & 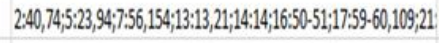 \\
\hline & book & $17: 13-14,13 a ; 18: 49,498 ; 23: 62 ; 34: 3 ; 366: 12 ; 39 ;: 69 ; 45: 28,28 ; ; 50 ;$ \\
\hline & book of deeds & $17: 13-14,13 a ; 18: 49,498 ; 23: 62 ; 343 ; 3 ; 36: 12 ; 39 ;: 69 ; 45: 28,288 ; 50 ;$ \\
\hline
\end{tabular}

Fig. 5 Replacing the Verse Number of Chapter 36 Into Thematic Group

Accordingly, all the number of verses is changed into the name of the thematic group and counted the total number of themes and a total number of assigned verses based on OQSEs. Which means, 71 groups of themes has become 71 thematic groups (TG) with a total of 302 themes. The research has put some criteria to narrow down this 71 thematic groups for later justification by a mean of convenience sampling [24], [25]. Applying this criterion, there are 40 thematic groups left with 214 themes. Later on, these 214 themes are categorized into several sets to form up the questionnaires for Delphi study.

Consequently, there are 10 verses have been selected for each thematic group (TG) by simple random sampling. Since all the verses for a thematic group have equal chance to be chosen for the research as all these verses are related to the themes [26], choosing either all or few would indicate the same. For example, if thematic group A got 50 assigned verses according to OQSE, justifying all those 50 verses whether or not related with the theme is as same as justifying 10 verses among that 50 can give the same result.

Which is why a simple random sampling process has been conducted using RapidMiner to choose 10 verses for each thematic group. Likewise, 40 thematic groups with 10 verses in each group become $40 \times 10=400$ verses. However, the result of comparative research in preliminary data collection through stage 1 is the compilation of 40 thematic groups (TG), 400 verses divided into 10 sets. This data is justified in the second stage through Delphi study.

\section{MODIFIED DELPHI METHOD: DATA COLLECTION}

Modified Delphi method is the second stage of this research. The purpose of this method is to collect experts' consensus on the preliminary data which were accumulated by comparative research among eight OQSEs. The aim of this method is to accomplish the second objective of this research by several technical questions towards the experts. In this method, the experts are to give their open opinion 
about the assigned verses against the assigned themes. Below the process of two round Delphi study in Figure 6.

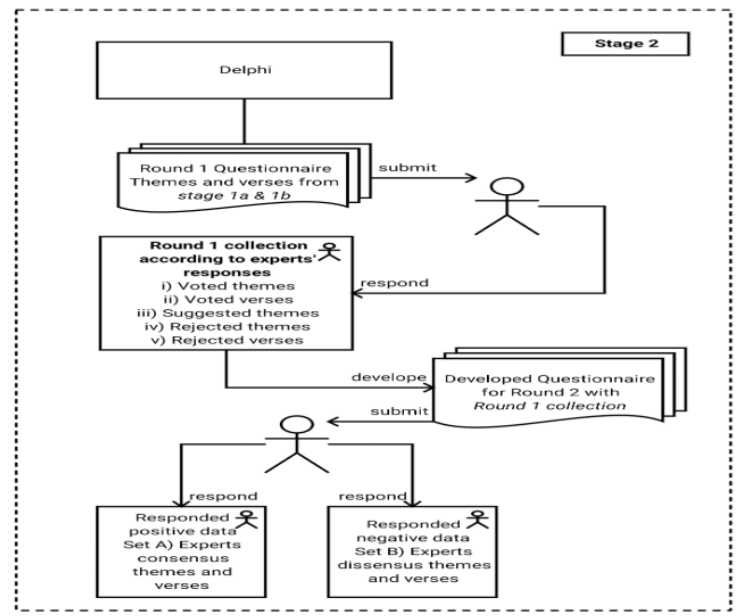

Process of 2 rounds Delphi study

Then the experts are expected to read the verses of each thematic group and tick the relevant theme(s). Experts have been given freedom to choose the appropriate theme against the verse or suggest their own natural theme for the verses.

In round two experts are given the same set of questionnaires but in a different format. This round is to get the confirmation of the same panellists who were involved in the first round of questionnaire. In this round, panellists check the themes which are mixed with their natural theme as well as a given theme in round one. Some themes of this round are added because of other panellists' suggestion and some themes have been removed based on the regulations of analysis of round one. The main purpose of this round is to get panellist' reconfirmation on the theme and relevant verses and sort out the theme from most relevant to least relevant against the highest relevant verses to lowest relevant verses.

\section{A. Round One Data Collection Responses}

A categorical variable is the most important part in Delphi study apart from the numerical variable. In categorical variable, the special people of respondents are identified based on the experts' criteria as research attributes before designing the Delphi questionnaire. The main purpose of the categorical variable is to display the demographic data in the frequency table. However, the firstround questionnaire has been distributed to the expert panellists through a nominating process where each respondent should be agreed to join in these two round Delphi studies. An official invitation letter has been attached to the questionnaire. Out of thirty experts, only 20 persons responded for the first round questionnaire. Having received their responses, it is assumed that they are ready to join the whole process of two round Delphi study.

\section{Summary of Round One}

Round one was designed with ten sets of questionnaires with 214 themes and 400 verses. These themes and verses were found and sorted out through comparative research in stage one. Out of 214 themes, panellists agreed upon with 182 themes with 398 aligned verses out of 400 verses. There are five categories of data found after analyzing round one response:

Round 1 Collection:

i.Voted themes- themes with relevance percentage (50\% and $100 \%) .182$ themes in total. 
ii.Voted verses- 398 verses except for a verse from TG1 and TG8.

iii.Suggested themes- themes which were additionally suggested for some thematic groups. 107 themes were suggested by experts.

iv.Rejected themes- themes which have received $0 \%$ consensus in the thematic group. There are 32 themes found with $0 \%$ relevance.

v. Rejected verses- verses which were found irrelevant in the thematic group. There are 2 verses found not relevant out of 400 verses.

\section{B. Round Two Data Collection}

Second round Delphi study was designed with the results of first round Delphi responses (round 1 collection). In this round, experts were required to read the themes and find the most relevant verse from the group. Likewise round one, second round was also designed with ten sets of questionnaires with 40 thematic groups. Each set contains four thematic groups and each group consists of verses and themes. Themes which were suggested additionally in round one as well as themes which received consensus by the experts in round one. Therefore, out of 214 themes, there are 182 voted themes with 107 suggested themes have been included in round two which is total of 285 themes in 40 thematic groups. Since two verses were rejected by the experts in round one, the second round questionnaire did not consider that either.

The purpose of this round is to get reconfirmation of experts on the themes and the aligned verses of each thematic group and identify relevant themes by recording the highest relevant verses to the theme. As it has been explained in methodology, the analysis of round two data followed with the formula below:

$$
\begin{aligned}
& \text { *Experts' recall (ER) score }-\frac{a}{b} \times 100 \\
& \qquad \begin{aligned}
a & =\text { Total number of retrieved relevant verses } \\
b & =\text { Total number of relevant verses }
\end{aligned}
\end{aligned}
$$

Set $\boldsymbol{A}$ refers to experts' consensus themes and verses according to the stage 2 analysis procedure. This set contains two types of findings:

1. List of confirmed verses which are relevant to the themes.

2. Important themes which are semantically closer to the relevant verses comparing to all other themes in a TG.

Set $B$ refers to experts dissensus themes and verses unlike set $A$.

\section{Summary of Round Two}

In the second round of Delphi study, the responses are to collect to finalize the thematic relations with the relevant verses. The panellists were supposed to identify the highest recall of relevant verses against each theme from each thematic group. In that sense, there are two categories of data has been justified through stage 2- modified Delphi method.

Set A: 240 themes received experts' consensus with ER score. By having this set, two kinds of data are confirmed in this stage (stage 2).

1. Verses: List of confirmed verses which are relevant to the themes. Set A has categorized the themes which received experts' relevance frequency or ER value and this $R$ has been justified against the verses in each TG. Hence, a theme has ER means there is a relevant verse(s). Most relevant themes: Important themes which are semantically closer to the relevant verses comparing to all other themes in a TC.

Set B: 45 themes received experts' dissensus with o ER score.

\section{ANALYSIS AND FINDINGS}

\section{A. Relevant Verses Pertaining to the Themes}

The relevant Qur'ānic verses pertaining to Tafseer alMawdu iy or TlaQ has been stated based on the findings. This finding has been identified through experts' consensus on the verses, which were assigned by online Qur'ānic search engines (OQSES). The verses have been assembled in several sections as a thematic group (TG) (40 TG) (Stage 1) based on the thematic correlation. Therefore, the findings have been constructed on that thematic group category.

\section{B. Experts' Justification over OQSE}

The second part of question two (RQ2.2) was in what extent the experts' ER value draw the level of best ordination category over OQSEs value. The OQSEs refer to the themes and the verses collected in stage 1 (the compilation of eight OQSE). This compilation of verses and themes are assumed to be relevant and justified by experts as the literature said. Therefore, the percentage of relevant verses against the themes in that compilation is at least should be close to $100 \%$ relevant. On the contrary, the ER score of relevance frequency of that compiled themes and verses by the expert (in stage 2 of this research) found that the relevance result is not closer enough to $100 \%$. The aim of this question is to distinguish between the relevance frequency of compiled themes and verses from OQSE with experts' justification. 
However, the justification has found that it is not $100 \%$ relevant. Although the justification (ER) has been done based on 285 themes as representative of 400 verses (dividing into 40 thematic groups) from that compilation of OQSE, it is assumed that the all the themes of each thematic group can retrieve all the relevant verses since all the verses were assigned by OQSE as relevant to their themes/index topics.

After calculating the average frequency of all 40 thematic groups (TG), there are only 16 TG found where the average relevance frequency (Mean) is over $50 \%$. The rest (40-16) 24 TGs have gained the Mean below 50\%. This proves that the themes and relevant verses offered by OQSE's (compilation) are not 100\% (40/40) organized and aligned. By experts' justification, it has revealed that the accuracy of the ordination of the themes and verses in OQSE is 40\% (16/40) only. In the same manner, the result also said that 85 themes out of 240 have achieved ER score of more than $50 \%$. So, the accuracy of the ordination of themes and verses in OQSE could be justified with this percentage also $(85 / 240) \times 100=$ $35.41 \%$.

\section{CONCLUSION:}

According to the results, the research has accomplished its achievement based on the expectation it has underlined in research objectives. The first outcome it has achieved is the Reviews of literature for the existing methods of Qur'ānic search retrieval system. It has found that the research in Qur'ānic search is currently active and many researchers are developing the Qur'ānic search retrieval system using various methods. Despite the active research in the Qur'annic field, the theoretical gap still found in OQSEs. It has inspired this research and probably more research to be conducted in future to resolve the gap from all aspects of the Holy Qur'an. Besides, when there is a necessity to involve experts to justify the Qur'annic search retrieval results, and it has been seen that researchers also involved them in their experiment, a hybrid and more reliable method like Delphi method is important in this case. Nevertheless, no research in Qur'ānic search retrieval system was found, which has applied this hybrid method.

Consequently, the second achievement of the result was the extraction of online Qur'ānic search engines (OQSEs) along with the themes and the aligned verses. There were 214 themes initially extracted from the 8 OQSEs with 400 aligned verses. The fourth achievement was the final list of themes and the verses which were justified by the experts. There were 240 themes and 398 verses have been systematically justified by a group of panels from the Qur’ānic domain.

\section{REFERENCES}

[1] T. G. Armstrong, A. Moffat, W. Webber, and J. Zobel, "Has adhoc retrieval improved since 1994?," in Proc. 32nd Annual International ACM SIGIR Conference, 2009, pp. 692-693.

[2] T. G. Armstrong, A. Moffat, W. Webber, and J. Zobel, "Improvements that don't add up: ad-hoc retrieval results since 1998," in Conference on Information and Knowledge Management, 2009, pp. 601-610.

A. Trotman, A. Puurula, and B. Burgess, "Improvements to BM25 and Language Models Examined," ADCS '14, Novemb. 27 - 28 2014, Melbourne, VIC, Aust., pp. 1-9, 2014.

[4] R. Othman and A. A. Salahuddin, "Relevance status value model of Index Islamicus on Islamic History and Civilizations," Int. J. Web Inf. Syst., vol. 11, no. 1, pp. 54-86, 2015.

[5] K. Sparck Jones, S. Walker, and S. E. Robertson, “A probabilistic model of information retrieval: development and comparative experiments:: Part 1," Inf. Process. Manag., vol. 36, no. 6, pp. 809840, 2000.

[6] A. Ismail, T. M. T. Sembok, and H. B. Zaman, "Search engines evaluation using precision and document-overlapmeasurements at 10-50 cutoff points," 2000 TENCON Proceedings. Intell. Syst. Technol. New Millenn. (Cat. No.00CH37119), vol. 3, 2000.

K. Sparck Jones, K. Sparck Jones, S. Walker, S. Walker, S. E. Robertson, and S. E. Robertson, "A probabilistic model of information retrieval: development and comparative experiments Part 2," Inf. Process. Manag., vol. 36, pp. 809-840, 2000.

C. D. Manning and P. Raghavan, "An Introduction to Information Retrieval," 2009.

T. Mukhtar, H. Afzal, and A. Majeed, "Vocabulary of Quranic Concepts: A semi-automatically created terminology of Holy Quran," in 2012 15th International Multitopic Conference (INMIC), 2012, pp. 43-46.

[10] A. M. Sultan, A. Azman, R. A. Kadir, and M. T. Abdullah, "Evaluation of Quranic text retrieval system based on manually indexed topics," 2011 Int. Conf. Semant. Technol. Inf. Retrieval, STAIR 2011, no. June, pp. 156-161, 2011.

[11] H. A. Rahman and S. A. Noah, "A comparative analysis of the entropy and transition point approach in representing index terms of literary text," J. Comput. Sci., vol. 7, no. 7, pp. 1088-1093, 2011.

[12] H. A. Rahman, S. A. Noah, and H. Jimenez-Salazar, "Measuring the representativeness of index terms in literary texts: An experiment on the Quran," Proc. - Int. Symp. Inf. Technol. 2008, ITSim, vol. 2, pp. 6-10, 2008.

[13] R. Ismail, Z. Abu Bakar, and N. Abd. Rahman, "EXTRACTING KNOWLEDGE FROM ENGLISH TRANSLATED QURAN USING NLP PATTERN," J. Teknol., vol. 77, no. 19, pp. 67-73, Nov. 2015.

[14] M. El-Mesawi, “The Methodology of al-Tafsir al-Mawdu'i: A Comparative Analysis," Intellect. Discourse, vol. 130, pp. 400-408, 2005.

[15] R. Othman and F. A. Wahid, "Quranic Texts Retrieval in Indri," Inf. Commun. Technol. Muslim World (ICT4M), 20145 th Int. Conf., pp. 14, 2014 .

[16] E. Moyotl-hern and H. Jiménez Salazar, "An Analysis on Frequency of Terms for Text Categorization,” Proces. del Leng. Nat., no. №33, 
pp. 141-146, 2004.

[17] M. Menacer and A. Arbaoui, "Content extraction of Quran Interpretation (Tafseer) books for digital content creation and distribution," in 2013 World Congress on Computer and Information Technology (WCCIT), 2013, pp. 1-3.

[18] G. J. Skulmoski and F. T. Hartman, "The Delphi Method for Graduate Research,” J. Inf. Technol. Educ., vol. 6, no. 1, pp. 1-21, 2007.

[19] G. Rowe and G. Wright, "The Delphi technique as a forecasting tool: issues and analysis," Int. J. Forecast., vol. 15, no. 4, pp. 353375, Oct. 1999.

[20] C. Hsu and Brian A. Sandford, "The Delphi Technique: Making Sense Of Consensus," Pract. Assessment, Res. Eval., vol. 12, no. 10 , 2007.

[21] J. Martyn and F. W. (Frederick W. Lancaster, Investigative methods in library and information science : an introduction. Information Resources Press, 1981.
[22] L.-A. Armitage, "Factors affecting the adjustment of Koreans studying in Australia | UTS Library," Thesis (M.A.), Swinburne University of Technology, 1999. [Online]. Available: http://find.lib.uts.edu.au/;jsessionid=3779E5AB88C9DB41860E12E 45122621E?R=OPAC_b1467112. [Accessed: 18-Apr-2017].

[23] C. H. Busha and S. P. Harter, Research methods in librarianship : techniques and interpretation. Academic Press, 1980.

[24] I. Etikan, S. A. Musa, and R. S. Alkassim, "Comparison of Convenience Sampling and Purposive Sampling," Am. J. Theor. Appl. Stat., vol. 5, no. 1, pp. 1-4, 2016.

[25] L. J. Wu Suen, H. M. Huang, and H. H. Lee, "A comparison of convenience sampling and purposive sampling," J. Nurs., vol. 61, no. 3, pp. 105-111, 2014.

[26] P. W. West, "Simple random sampling of individual items in the absence of a sampling frame that lists the individuals," New Zeal. J. For. Sci., vol. 46, no. 1, pp. 1-7, 2016 